Article

\title{
Glycation Interferes with the Expression of Sialyltransferases in Meningiomas
}

\author{
Philipp Selke ${ }^{1, *}$, Kaya Bork ${ }^{1}$, Tao Zhang ${ }^{2}{ }^{\oplus}$, Manfred Wuhrer ${ }^{2}{ }^{\oplus}$, Christian Strauss $^{3}$, Rüdiger Horstkorte ${ }^{1}$ \\ and Maximilian Scheer 1,3 (D) \\ 1 Medical Faculty, Institute for Physiological Chemistry, Martin-Luther-University Halle-Wittenberg, \\ 06114 Halle (Saale), Germany; kaya.bork@medizin.uni-halle.de (K.B.); \\ Ruediger.horstkorte@medizin.uni-halle.de (R.H.); maximilian.scheer@uk-halle.de (M.S.) \\ 2 Center for Proteomics and Metabolomics, Leiden University Medical Center, \\ 2333 ZA Leiden, The Netherlands; t.zhang@lumc.nl (T.Z.); m.wuhrer@lumc.nl (M.W.) \\ 3 Department of Neurosurgery, University Hospital Halle, 06120 Halle (Saale), Germany; \\ Christian.strauss@uk-halle.de \\ * Correspondence: philipp.selke@uk-halle.de; Tel.: +49-0-345-557-3814
}

check for updates

Citation: Selke, P.; Bork, K.;

Zhang, T.; Wuhrer, M.; Strauss, C.; Horstkorte, R.; Scheer, M. Glycation Interferes with the Expression of Sialyltransferases in Meningiomas. Cells 2021, 10, 3298. https://doi.org/ 10.3390/cells10123298

Academic Editor: Javier S. Castresana

Received: 5 November 2021

Accepted: 22 November 2021

Published: 25 November 2021

Publisher's Note: MDPI stays neutral with regard to jurisdictional claims in published maps and institutional affiliations.

\begin{abstract}
Meningiomas are the most common non-malignant intracranial tumors and prefer, like most tumors, anaerobic glycolysis for energy production (Warburg effect). This anaerobic glycolysis leads to an increased synthesis of the metabolite methylglyoxal (MGO) or glyoxal (GO), which is known to react with amino groups of proteins. This reaction is called glycation, thereby building advanced glycation end products (AGEs). In this study, we investigated the influence of glycation on sialylation in two meningioma cell lines, representing the WHO grade I (BEN-MEN-1) and the WHO grade III (IOMM-Lee). In the benign meningioma cell line, glycation led to differences in expression of sialyltransferases (ST3GAL1/2/3/5/6, ST6GAL1/2, ST6GALNAC2/6, and ST8SIA1/2), which are known to play a role in tumor progression. We could show that glycation of BEN-MEN-1 cells led to decreased expression of ST3Gal5. This resulted in decreased synthesis of the ganglioside GM3, the product of ST3Gal5. In the malignant meningioma cell line, we observed changes in expression of sialyltransferases (ST3GAL1/2/3, ST6GALNAC5, and ST8SIA1) after glycation, which correlates with less aggressive behavior.
\end{abstract}

Keywords: intracranial tumor; methylglyoxal; MGO; sialylation; tumorigenesis; posttranslational modification

\section{Introduction}

Meningiomas arise from the arachnoid and are the most common non-malignant intracranial tumor [1-5]. They are classified according to WHO (World Health Organization) in grades I, II, and III. The benign grade I represents the most frequent subtype $(>80 \%)$, and has a low risk of recurrence and slow growth $[5,6]$. As opposed to benign meningioma, grade III meningiomas (anaplastic, rhabdoid, and papillary subtype) are rare (1-3\%) and little is known about factors that influence their survival and malignity. The present surgical, medicinal, and radiotherapeutic treatments are not adequate to manage the morbidity and mortality in this subtype [7-10].

Like many other tumors, meningiomas use glucose as a primary energy source (Warburg effect), which is considered as one of the "hallmarks of cancer" [11-13].

During glycolysis, up to $0.4 \%$ of the glucose is converted into methylglyoxal (MGO). MGO is a typical side product of glyceraldehyde-3-phosphate, which is generated by the aldolase reaction from fructose-1,6-bisphosphate. Please note that MGO is more than 20,000 times more reactive than glucose [11]. Previous studies showed that MGO concentrations are elevated in diabetic and or aged individuals [14]. Many studies suggest that diabetes is linked to an increased risk of cancer $[15,16]$. In line with this, there is a correlation 
between serum glucose levels and meningioma risk [17,18]. However, there are contrary data suggesting a positive $[19,20]$ or inverse [21] correlation between diabetes and serum glucose levels and the risk of meningioma. For example, patients with type 2 diabetes have a decreased survival after surgical resection of a WHO grade I meningioma [22].

The dicarbonyl MGO reacts primarily with proteins (through arginine, lysine, and cysteine residues) or to a small extent also with DNA and lipids. This non-enzymatic reaction between the carbonyl groups of dicarbonyls (i.e., MGO) or monosaccharides (i.e., glucose) and the amino groups of proteins is called glycation $[23,24]$. Another important glycating agent is glyoxal (GO), which is formed by degradation of glucose or autoxidation of glycoaldehyde to glyoxal [25]. Glycation is much stronger with dicarbonyls than with monosaccharides [26]. The end products of this reaction are called advanced glycation end products (AGEs) [27-29]. Recently, we demonstrated that glycation through MGO led to an increased invasive behavior in benign meningioma cells [30]. Several other studies propose MGO as a tumor-promoting agent [31,32].

Another common posttranslational modification is glycosylation. In contrast to glycation, glycosylation is an enzymatic addition of carbohydrates, glycans to a noncarbohydrate-structure, commonly a lipid or protein in the endoplasmatic reticulum (ER)/Golgi. Sialylation is of deep interest and describes the addition of sialic acids (Sia) to lipids (i.e., gangliosides) or proteins (i.e., neural cell adhesion molecule (NCAM)) through sialyltransferases (ST) [33].

$\mathrm{N}$-acetyl neuraminic acid $\left(\mathrm{Neu}_{5} \mathrm{Ac}\right)$ represents the major Sia of mammals. It is synthesized from UDP- $N$-acetyl glucosamine (UDP-GlcNAc) in the cytosol [34]. The key enzyme of the Sia biosynthesis is the bifunctional UDP- $\mathrm{N}$-acetyl glucosamine 2-epimerase/ $\mathrm{N}$ acetyl mannosamine kinase (GNE) [35]. Sialylation is taking place in the Golgi and is catalyzed by STs. They are 20 known STs in humans, which use CMP-activated Sia as substrate (Figure 1). These STs are subdivided into 4 families dedicated to the carbohydrate linkages they synthesize: beta-galactoside alpha 2,3-sialyltransferases (ST3Gal1-6), beta-galactoside alpha 2,6-sialyltransferases (ST6Gal1-2), $N$-acetyl galactosamine (GalNAc) alpha 2,6-sialyltransferases (ST6GalNAc1-6) and alpha 2,8-sialyltransferases (ST8Sia16) $[36,37]$. The members of the ST3Gal family transfer Sia from CMP-Sia to terminal galactose residues through 2,3 linkages, whereas the two known members of the ST6Gal family do this through 2,6 linkages. The six members of the ST6GalNAc family transfer Sia from CMP-Sia to GalNAc residues via 2,6 linkages. In addition, the ST8Sia-family transfer Sia from CMP-Sia to other terminal Sia residues by 2,8-linkages [36,37]. High blood glucose concentrations in individuals with diabetes result in a UDP-GlcNAc-dependent change to more complex $N$-glycans [38]. Especially, glycoproteins with only few $N$-glycosylation sites such as transforming growth factor $\beta$ (TGF $\beta$ ) or glucose transporter 4 (GLUT4) show rapid response to increasing GlcNAc concentrations causing complex glycan formation and branching [39]. Gangliosides are glycosphingolipids that contain Sias. The synthesis of gangliosides begins with ceramide (Cer) in the ER. During GM3-synthesis, Cer will be glucosylated by the glucosylceramid synthase. After this step in the cis-golgi, glucosylceramide is converted in the trans-golgi to lactosylceramide [40]. This is the substrate for GM3-synthase (ST3Gal5). It is known that GM3 plays a role during several diseases (chronic inflammation, insulin resistance or cancer) [41-43].

In this study, we compared the expression of STs in benign and malignant meningioma cells and found significant differences between these two. Furthermore, we investigated the role of the glycating metabolite MGO on the expression of STs in both benign and malignant meningioma cells. Thereby, we could show that glycation has a dramatic effect on the expression of STs and consequently on the GM3 expression. As a result, this could change sialylation-dependent tumor progression in meningioma. 


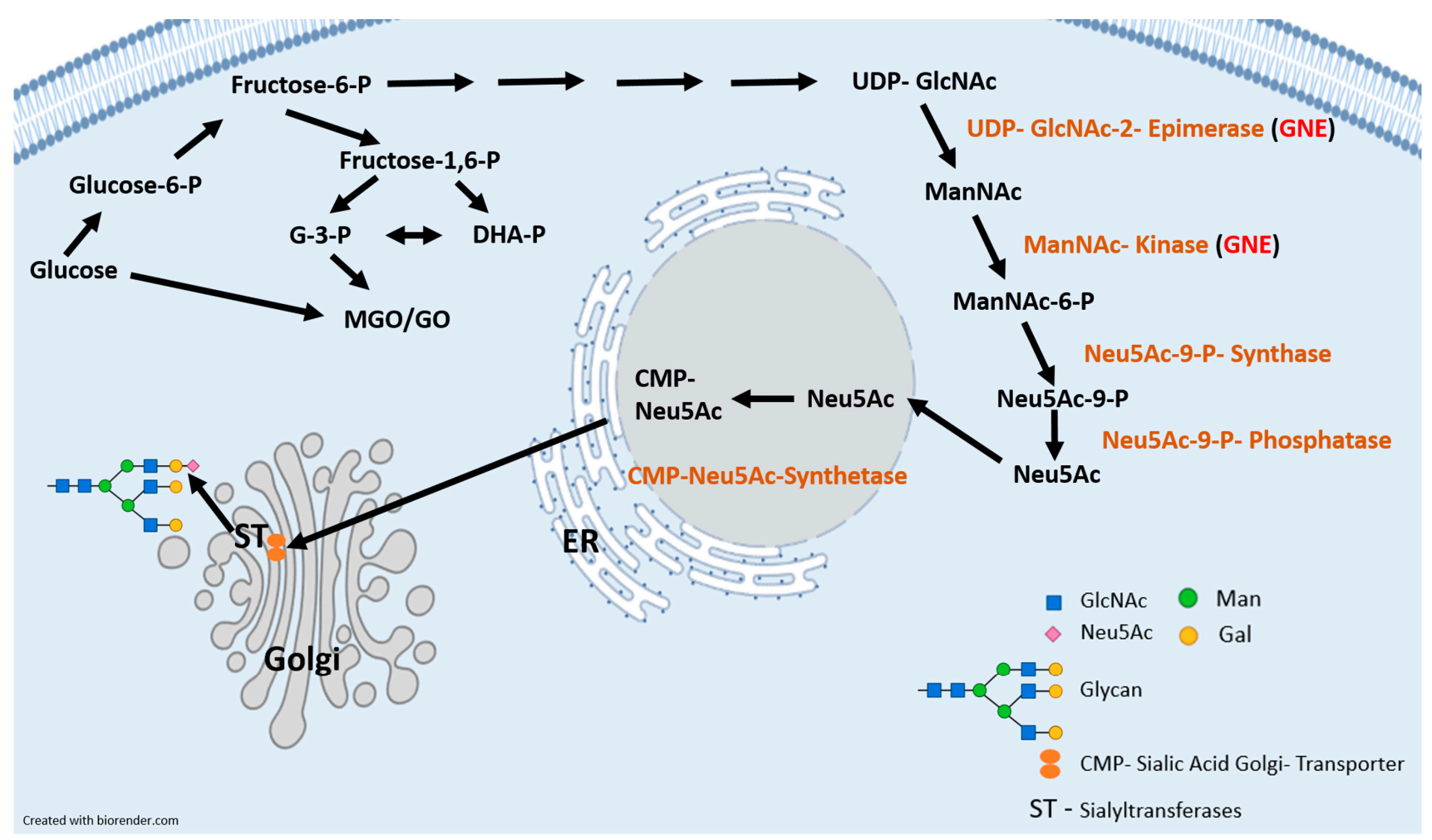

Figure 1. Schematic representation of the Sia biosynthesis from glucose to Sia and glycation agents (MGO/GO) and sialylation of glycoproteins (i.e., $\mathrm{N}$-glycans, $\mathrm{O}$-glycans or gangliosides) in the endoplasmatic reticulum and Golgi. G-3-P = glyceraldehyde-3-phosphate; DHA-P = Dihydroxyaceton phosphate; MGO = methylglyoxal; $\mathrm{GO}=$ glyoxal; GlcNAc = N-acetyl-glucosamine; Man = Mannose; Gal = Galactose; Neu5Ac = N-acetyl-neuraminic acid; GNE = UDP- $N$-acetyl glucosamine 2-epimerase $/ N$-acetyl mannosamine kinase; ER = Endoplasmatic reticulum .

\section{Materials and Methods}

\subsection{Cell Culture}

The human benign meningioma cell line BEN-MEN-1 was obtained from LeibnizInstitute DSMZ (Deutsche Sammlung von Mikroorganismen und Zellkulturen GmbH, Braunschweig, Germany) and the human malignant meningioma cell line IOMM-Lee (ATCC ${ }^{\circledR}$ CRL-3370 ${ }^{\mathrm{TM}}$ ) was obtained from American Type Culture Collection (ATCC, Manassas, VA, USA). Both cell lines were cultured in Dulbecco's Modified Eagle's Medium (DMEM) supplemented with $100 \mu \mathrm{g} / \mathrm{mL}$ of streptomycin, $100 \mathrm{U} / \mathrm{mL}$ of penicillin, $4 \mathrm{mM}$ of glutamine, and 10\% fetal bovine serum (FBS, Sigma-Aldrich, St. Louis, MO, USA) at $37{ }^{\circ} \mathrm{C}$ in a $5 \% \mathrm{CO}_{2}$ incubator. The cell lines were split every $2-3$ days with $0.1 \%$ Trypsin-EDTA (Ethylenediaminetetraacetic acid) solution for $2 \mathrm{~min}$.

\subsection{Glycation and Real-Time PCR Analysis}

Cells were seeded in 12-well plates at a density of $3.95 \times 10^{4} / \mathrm{cm}^{2}$ in DMEM with $1 \%$ FBS. After $2 \mathrm{~h}$ of attachment, the cells were treated with $0.3 \mathrm{mM}$ MGO or GO. Controls (Ctrl) were cells (BEN-MEN-1, IOMM-Lee) without MGO or GO treatment. The cell lines were cultivated for $24 \mathrm{~h}$. RNA was isolated using the Quick-RNA ${ }^{\mathrm{TM}}$ MiniPrep Kit (Zymo Research, Irvine, CA, USA) according to the manufacturer's instructions. The quality and concentration of the RNA were analyzed using the NanoDrop 1000 Spectrophotometer (Thermo Fisher Scientific, Waltham, MA, USA). RNA $(2 \mu \mathrm{g})$ was transcribed into cDNA using SuperScript ${ }^{\mathrm{TM}}$ II Reverse Transcriptase according to the manufacturer's instructions. PCR reactions were performed using DreamTaq DNA polymerase (Thermo Fisher Scientific), and products were separated on a $1.5 \%$ agarose gel. The following conditions were used: initial denaturation for $2 \mathrm{~min}$ at $95^{\circ} \mathrm{C}, 35$ cycles $\left(30 \mathrm{~s}\right.$ at $95^{\circ} \mathrm{C}, 30 \mathrm{~s}$ at $55^{\circ} \mathrm{C}, 30 \mathrm{~s}$ at 
$72{ }^{\circ} \mathrm{C}$ ), final elongation for $5 \mathrm{~min}$ at $72{ }^{\circ} \mathrm{C}$. We use for all sialyltransferases the same primer pairs which were used in a previous study [44].

The sialyltransferase expression of untreated meningioma cell lines (BEN-MEN-1; IOMM- Lee) and after $24 \mathrm{~h}$ of glycation with $0.3 \mathrm{mM}$ MGO were measured via quantitative real-time PCR (qPCR) using the $\mathrm{iQ}^{\mathrm{TM}} 5$ Multicolor Real-Time PCR Detection System (Biorad, Hercules, CA, USA) and qPCR GreenMaster (Jena Bioscience, Jena, Germany) with the same primer pairs used for normal PCR. The following conditions were used for qPCR: initial denaturation for $1: 30 \mathrm{~min}$ at $95^{\circ} \mathrm{C}, 40$ cycles $\left(10 \mathrm{~s}\right.$ at $95^{\circ} \mathrm{C}, 10 \mathrm{~s}$ at $62^{\circ} \mathrm{C}, 25 \mathrm{~s}$ at $\left.72{ }^{\circ} \mathrm{C}\right)$, final elongation for $1 \mathrm{~min}$ at $72{ }^{\circ} \mathrm{C}$, followed by a melting curve analysis. The expression level of sialyltransferases in control and glycated cell lines was determined relative to GAPDH (165 bp; fw: GGAGCGAGATCCCTCCAAA; rv: ATGACGAACATGGGGGCATC), calculated as $\triangle \mathrm{CT}$. The control was relatively computed to glycated cell line $\left(2^{-\Delta \Delta \mathrm{CT}}\right)$. All reactions were performed in triplicate.

\subsection{Cultivation of BEN-MEN-1 Cells and Preparation of GSL-Glycan Alditols Released from BEN-MEN-1 Cells}

Extraction of GSLs and preparation of GSL-glycan alditols from cells were performed in triplicate as previously described [45]. The cells were cultivated until $80 \%$ of confluence and followed by $24 \mathrm{~h}$ treatment with and without $0.3 \mathrm{mM} \mathrm{MGO}$. Shortly, $2 \times 10^{6}$ cells were harvested, washed and resuspended with $200 \mu \mathrm{L}$ of water. The cell samples were lysed by vortexing and sonication for $30 \mathrm{~min}$. In this step, $2.5 \mu \mathrm{L}$ of $0.5 \mu \mathrm{M}$ ganglioside GT1b in ethanol were added as a spiked internal standard to monitor sample preparation and to normalize roughly absolute quantification. Chloroform $(550 \mu \mathrm{L})$ was added to the samples followed by $15 \mathrm{~min}$ sonication. Methanol $(350 \mu \mathrm{L})$ was added to the cell pellets and incubated for $4 \mathrm{~h}$ with shaking at room temperature. The upper phase containing GSLs was collected after centrifugation at $2700 \times g$ for $20 \mathrm{~min}$. Then, $400 \mu \mathrm{L}$ of chloroform $/$ methanol $(2: 1, v / v)$ was added, followed by adding $400 \mu \mathrm{L}$ of methanol/water $(1: 1, v / v)$. After sonication and centrifugation, the upper phase was collected and pooled to the previous sample. The process of adding methanol/water $(1: 1, v / v)$, sonication, centrifugation and removing the upper phase was repeated another two times. In each replicate, the upper phase was collected and replaced by the same volume of methanol/water $(1: 1, v / v)$. The combined upper phases were dried under vacuum in an Eppendorf Concentrator 5301 (Eppendorf, Hamburg, Germany) at $30^{\circ} \mathrm{C}$.

Before the purification of the GSLs using reverse-phase (RP) SPE, the samples were dissolved in $100 \mu \mathrm{L}$ methanol followed by the addition of $100 \mu \mathrm{L}$ water. TC18-RP-cartridges were prewashed with $2 \mathrm{~mL}$ of chloroform/methanol $(2: 1, v / v), 2 \mathrm{~mL}$ of methanol followed by equilibration with $2 \mathrm{~mL}$ methanol/water $(1: 1, v / v)$. The extracted GSLs were loaded to the cartridge and washed with $2 \mathrm{~mL}$ methanol/water $(1: 1, v / v)$. The GSLs were eluted from the column with $2 \mathrm{~mL}$ methanol and $2 \mathrm{~mL}$ chloroform/methanol $(2: 1, v / v)$. The samples were dried under vacuum in an Eppendorf Concentrator at $30^{\circ} \mathrm{C}$.

To release the glycans from the GSLs, a mixture of EGCase I (12 mU, $2 \mu \mathrm{L})$, EGCase I buffer $(4 \mu \mathrm{L})$ and water $(34 \mu \mathrm{L})(\mathrm{pH} 5.2)$ was added to each sample and incubated for $36 \mathrm{~h}$ at $37^{\circ} \mathrm{C}$. The released glycans were collected and loaded on TC18-RP-cartridges, which had been preconditioned with $2 \mathrm{~mL}$ of methanol and $2 \mathrm{~mL}$ of water. The samples were washed with $200 \mu \mathrm{L}$ of water and residual glycans were loaded to the cartridge. Then, $500 \mu \mathrm{L}$ of water were added to the cartridge to wash the glycans from the column. The flow-through and wash fractions were pooled and dried in an Eppendorf Concentrator at $30{ }^{\circ} \mathrm{C}$.

The reduction was carried out with slight modifications following the same procedure as described in previous work $[45,46]$. In brief, GSL-glycans were reduced to alditols in $20 \mu \mathrm{L}$ of sodium borohydride $(500 \mathrm{mM})$ in potassium hydroxide $(50 \mathrm{mM})$ for $2 \mathrm{~h}$ at $50{ }^{\circ} \mathrm{C}$. Subsequently, $2 \mu \mathrm{L}$ of glacial acetic acid were added to acidify the solution and quench the reaction. The desalting of GSL-glycans was performed as previously described. Glycan alditols were eluted with $50 \mu \mathrm{L}$ of water twice. The combined flow-through and eluate were pooled and dried under vacuum in an Eppendorf Concentrator at $30^{\circ} \mathrm{C}$. The 
carbon SPE clean-up was performed and the purified glycan alditols were re-suspended in $20 \mu \mathrm{L}$ of water prior to Porous Graphitized Carbon (PGC) nano-Liquid Chromatography (LC)-Electro Spray Ionization (ESI)-Mass Spectrometry (MS)/MS/MS analysis.

\subsection{Analysis of GSL-Glycan Alditols Using PGC Nano-LC-ESI-MS/MS}

The analysis of glycan alditols was performed using PGC nano-LC-ESI-MS/MS following a method described previously $[45,46]$. Measurements were performed on an Ultimate 3000 Ultra-High-Performance Liquid Chromatography (UHPLC) system (Thermo Fisher Scientific) equipped with a home-packed PGC trap column (5 $\mu \mathrm{m}$ Hypercarb, $320 \mu \mathrm{m} \times 30 \mathrm{~mm}$ ) and a home-packed PGC nano-column (3 $\mu \mathrm{m}$ Hypercarb $100 \mu \mathrm{m} \times$ $150 \mathrm{~mm}$ ) coupled to an amaZon ETD speed ion trap (Bruker, Bremen, Germany). Mobile phase A consisted of $10 \mathrm{mM} \mathrm{ABC}$, while mobile phase $B$ was $60 \%(v / v)$ acetonitrile $/ 10 \mathrm{mM}$ $\mathrm{ABC}$. The trap column was packed with $5 \mu \mathrm{m}$ particle size PGC stationary phase from Hypercarb PGC analytical column (size $100 \times 4.6 \mathrm{~mm}, 5 \mu \mathrm{m}$ particle size, Thermo), while the PGC nano-column was packed with $3 \mu \mathrm{m}$ particle size PGC stationary phase from Hypercarb PGC analytical column (size $30 \times 4.6 \mathrm{~mm}, 3 \mu \mathrm{m}$ particle size, Thermo).

To analyze glycans, $2 \mu \mathrm{L}$ injections were performed and trapping was achieved on the trap column using a $6 \mu \mathrm{L} / \mathrm{min}$ loading flow in $1 \%$ solvent B for $5 \mathrm{~min}$. Separation was achieved with a linear gradient from $1 \%$ to $50 \%$ solvent $B$ over 73 min, applied followed by a $10 \mathrm{~min}$ wash step using $95 \%$ of $\mathrm{B}$ at a $0.6 \mu \mathrm{L} / \mathrm{min}$ flow rate. The column was held at a constant temperature of $35^{\circ} \mathrm{C}$.

Ionization was achieved using the nanoBooster source (Bruker) with a capillary voltage of $1000 \mathrm{~V}$ applied and a dry gas temperature of $280^{\circ} \mathrm{C}$ at $3 \mathrm{~L} / \mathrm{min}$ and isopropanol enriched nitrogen at 3 psi. MS spectra were acquired within an $\mathrm{m} / \mathrm{z}$ range of $340-1850$ in enhanced mode using negative ion mode, smart parameter setting was set to $\mathrm{m} / \mathrm{z} 900$. MS/MS spectra were recorded using the top 3 highest intensity peaks.

Structures of detected glycans were studied by MS/MS in negative mode. Glycan structures were assigned based on the known MS/MS fragmentation patterns in negativeion mode $[47,48]$, elution order, and general glycobiological knowledge, with the help of Glycoworkbench [49] and Glycomod [50] software. To get an estimate of the glycan amount per cell, glycan intensity was normalized to the intensity of the internal standard GT1b. Then, assuming complete release of glycans and similar response factors between released glycan and GT1b standard, the number of glycans per cell was estimated.

Structures are depicted according to the Consortium of Functional Glycomics (CFG). Blue square is $\mathrm{N}$-acetylglucosamine; yellow square is $\mathrm{N}$-acetylgalactosamine; blue circle is glucose; yellow circle is galactose; red triangle is fucose; purple diamond is $\mathrm{N}$ acetylneuraminic acid, grey diamond is $\mathrm{N}$-glycolylneuraminic acid.

\subsection{Statistical Analysis}

All analyses and visualizations were performed using OriginPro 2019 software (OriginLab Corporation, Northampton, MA, USA). Paired Student $t$-test against the control group, both cell lines of a theoretical value of 1 (due to data normalization), were executed. Figures show the average mean with standard deviation (SD) and levels of significance are represented within the figures.

\section{Results}

\subsection{Expression of Sialyltransferases in Meningioma Cell Lines}

Since there is evidence that sialyltransferases have an impact on tumorigenesis, we analyzed benign (BEN-MEN-1) and malignant (IOMM-Lee) meningioma cell lines regarding differences in expression of sialyltransferases (Figure 2, Table 1). Figure 2A shows the expression of ST3GAL1-6 in BEN-MEN-1 and IOMM-Lee. ST3GAL1-ST3GAL3 and ST3GAL5-ST3GAL6 were detected in both cell lines. The band intensity of ST3GAL2 was higher in the malignant cell line compared with the benign cell line, whereas the ST3GAL3, ST3GAL5-6 band intensities were higher in BEN-MEN-1 compared to the malignant cell 
line. Agarose gel of ST6GAL1-2 is shown in Figure 2B for both cell lines. ST6GAL2 was only expressed in the benign cell line. In contrast, no differences could be found in terms of band intensity of ST6GAL1 in both cell lines. The expression of ST6GALNAC1-6 for both cell lines is shown in Figure 2C. In contrast to IOMM-Lee, a weak band in ST6GALNAC2 was detectable in BEN-MEN-1. Expression of ST6GALNAC4-6 was detectable in both cell lines. The band intensities of ST6GALNAC5 and ST6GALNAC6 were higher in IOMMLee compared to BEN-MEN-1. The expression of ST8SIA1-6 in both cell lines is shown in Figure 2D. For ST8SIA1-2 and ST8SIA5-6, the expression has been detected in both meningioma cell lines. In BEN-MEN-1, we observed a higher expression of ST8SIA2 and ST8SIA6 compared to the malignant cell line. Again, the band intensity of ST8SIA5 was stronger in IOMM-Lee compared to the benign cell line.

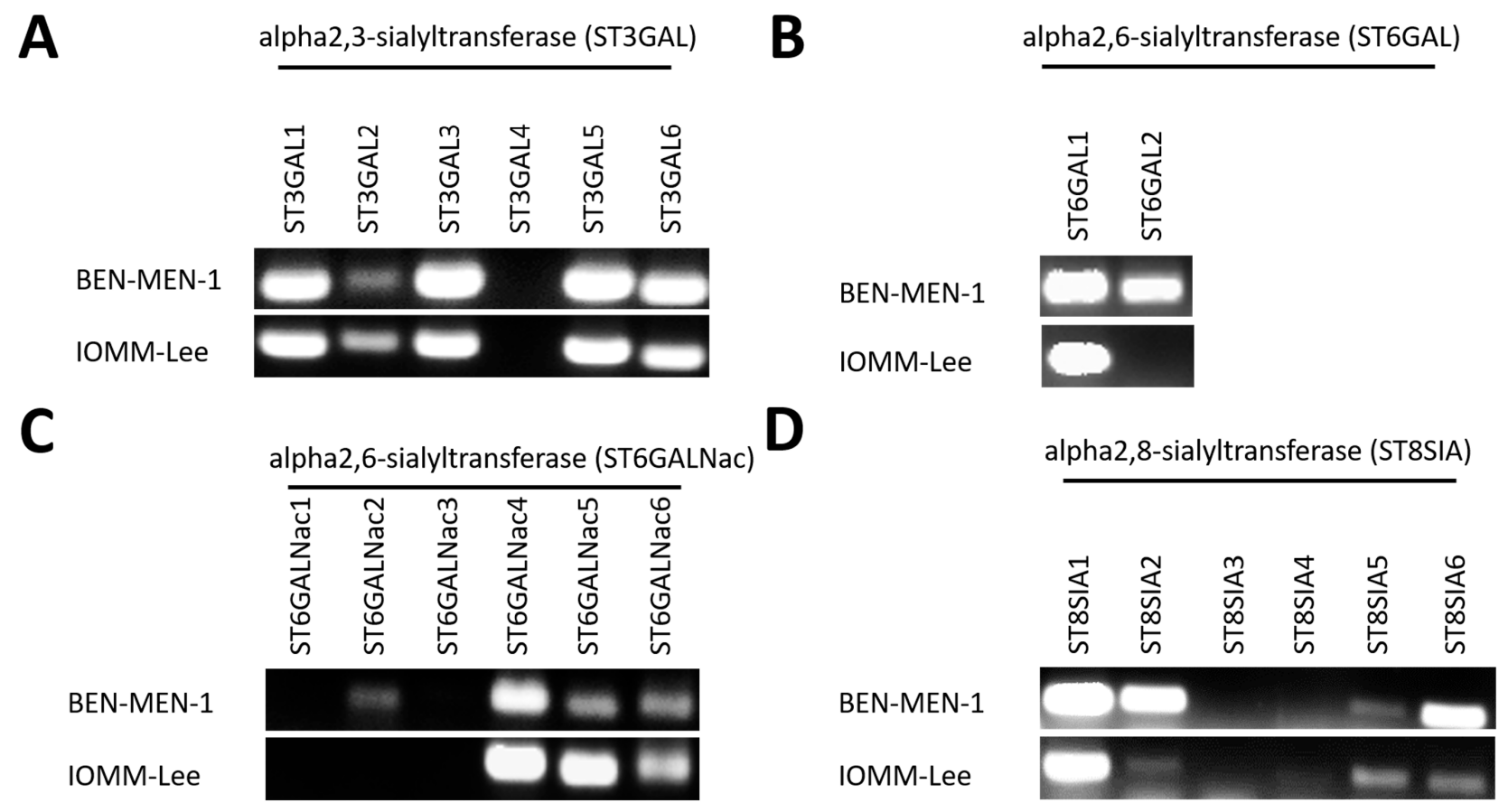

Figure 2. Expression of 20 Sialyltransferases (agarose gel) in BEN-MEN-1 and IOMM-Lee. (A): Expression of ST3GAL1-6. (B): Expression of ST6GAL1-2. (C): Expression of ST6GALNAC1-6. (D): Expression of ST8SIA1-6.

\subsection{Sialyltransferases Are More Affected by MGO in Benign Cell Line}

Since the expression of sialyltransferases is different in the benign and malignant meningioma cell lines, we quantified the sialyltransferase mRNA expression level after $24 \mathrm{~h}$ of glycation of the cells to verify the influence of glycation on sialylation. Figure 3 displays the different mRNA expressions of ST3GAL1-6 in BEN-MEN-1 (Figure 3A) and IOMM-Lee (Figure $3 \mathrm{~B}$ ). Glycation led to changes in ST expression. In the benign cell line, we observed an increased overall expression, whereas we noticed a decreased overall expression of STs in the malignant cell line. ST3GAL1 (1.4812 \pm 0.115 fold change), ST3GAL2 (3.143 \pm 0.476 fold change), and ST3GAL3 (1.28 \pm 0.189 fold change) expression were increased in contrast to non-glycated cells in BEN-MEN-1. Furthermore, the relative expression of ST3GAL5 ( $0.7863 \pm 0.0933$ fold change) and ST3GAL6 (0.572 \pm 0.126 fold change) were decreased in contrast to non-glycated cells. The relative expression of ST3GAL1 $(0.601 \pm 0.223$ fold change), ST3GAL2 (0.288 \pm 0.0535 fold change), ST3GAL3 ( $0.6175 \pm 0.217$ fold change), ST3GAL5 (0.4561 \pm 0.1271 fold change), ST3GAL6 (0.502 \pm 0.1325 fold change) were decreased in contrast to non-glycated cells in the malignant cell line. 
Table 1. Overview of sialyltransferase expressions in both meningioma cell lines.

\begin{tabular}{|c|c|c|}
\hline GENE & BEN-MEN-1 & IOMM-Lee \\
\hline ST3GAL1 & +++ & +++ \\
\hline ST3GAL2 & + & ++ \\
\hline ST3GAL3 & +++ & +++ \\
\hline ST3GAL4 & - & - \\
\hline ST3GAL5 & +++ & +++ \\
\hline ST3GAL6 & +++ & +++ \\
\hline ST6GAL1 & +++ & +++ \\
\hline ST6GAL2 & ++ & - \\
\hline ST6GALNAC1 & - & - \\
\hline ST6GALNAC2 & + & - \\
\hline ST6GALNAC3 & - & - \\
\hline ST6GALNAC4 & +++ & +++ \\
\hline ST6GALNAC5 & ++ & +++ \\
\hline ST6GALNAC6 & ++ & ++ \\
\hline ST8SIA1 & +++ & +++ \\
\hline ST8SIA2 & +++ & + \\
\hline ST8SIA3 & - & - \\
\hline ST8SIA4 & - & - \\
\hline ST8SIA5 & + & + \\
\hline ST8SIA6 & +++ & + \\
\hline
\end{tabular}

Table 1 shows overview of sialyltransferase expression in both meningioma cell lines. The expression levels are displayed in $+++=$ high expression level $;++=$ middle expression level $;+=$ low expression level $;-=$ no expression.

A

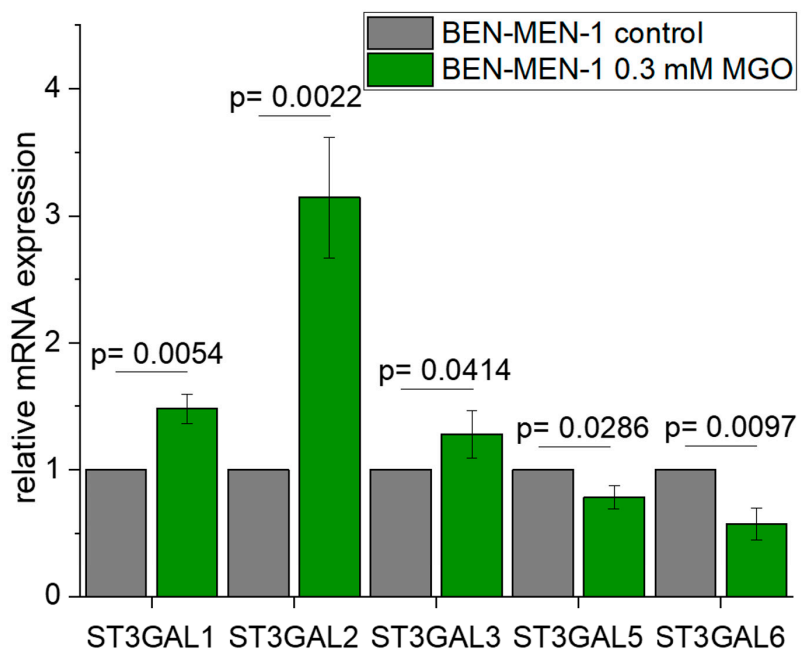

B

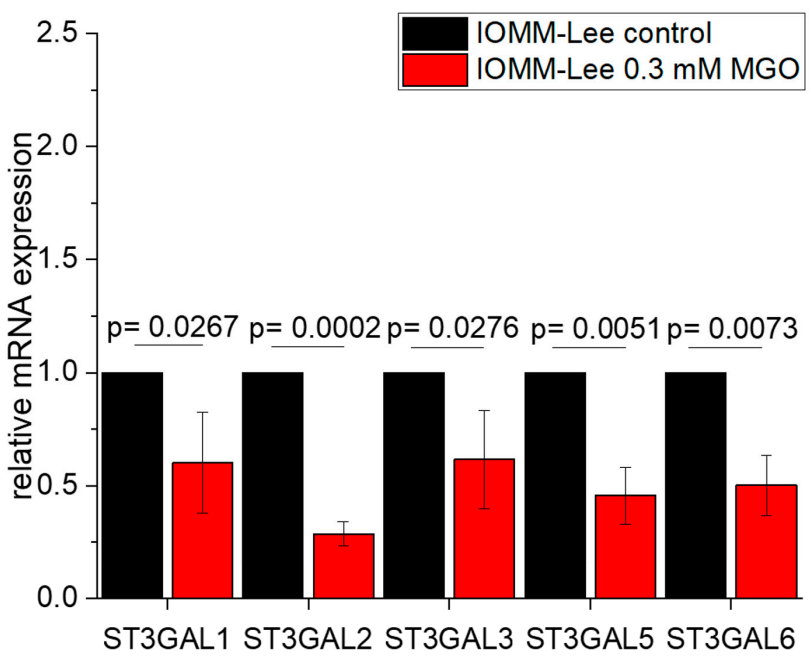

Figure 3. Relative mRNA expression of ST3GAL1-6 in BEN-MEN-1 (A) and IOMM-Lee (B). (A): Normalized control (grey) and mRNA expression after $24 \mathrm{~h}$ treatment with $0.3 \mathrm{mM} \mathrm{MGO}$ (green). (B): Normalized control (black) and mRNA expression after $24 \mathrm{~h}$ treatment with $0.3 \mathrm{mM}$ MGO (red). Statistical analysis was performed using $t$-test and error bars represent SD ( $\mathrm{n}=4$; ST3GAL1: $p=0.0054(\mathbf{A}), p=0.0267(\mathbf{B})$; ST3GAL2: $p=0.0022(\mathbf{A}), p=0.0002(\mathbf{B}) ;$ ST3GAL3: $p=0.0414$ (A), $p=0.0276$ (B); ST3GAL5: $p=0.0286$ (A), $p=0.0051$ (B); ST3GAL6: $p=0.0097$ (A), $p=0.0073$ (B)).

Figure 4 shows the expression of the ST6GAL-family in BEN-MEN-1 (Figure 4A) and IOMM-Lee (Figure 4B). Glycation led to opposing changes in the expression of this sialyltransferase. We observed a higher expression in the benign cell line after treatment with MGO (3.2402 \pm 0.962 fold change), whereas no changes could be measured in the glycated malignant cell line (1.018 \pm 0.164 fold change). The expression of ST6GAL2 was only detected in BEN-MEN-1 and increased after treatment with MGO (1.624 \pm 0.188 fold change). 
A

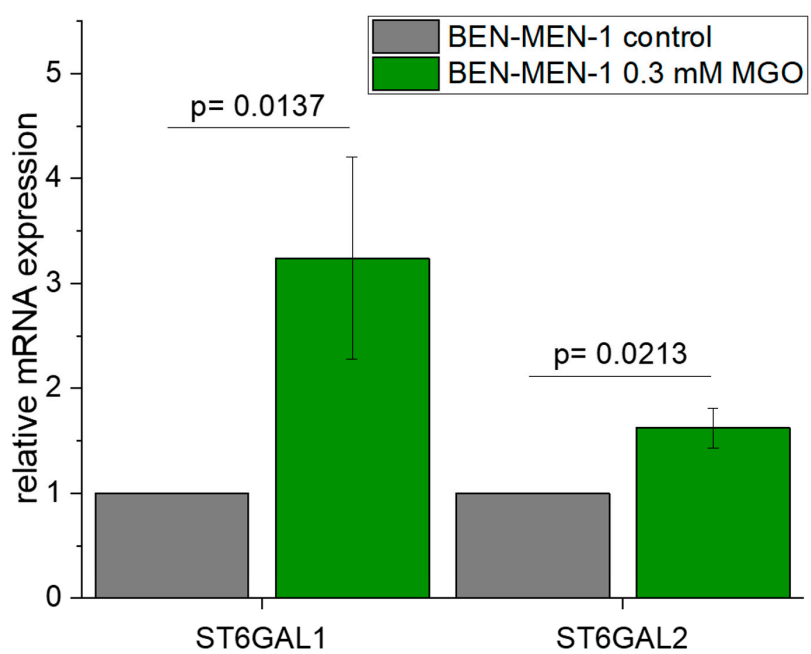

B

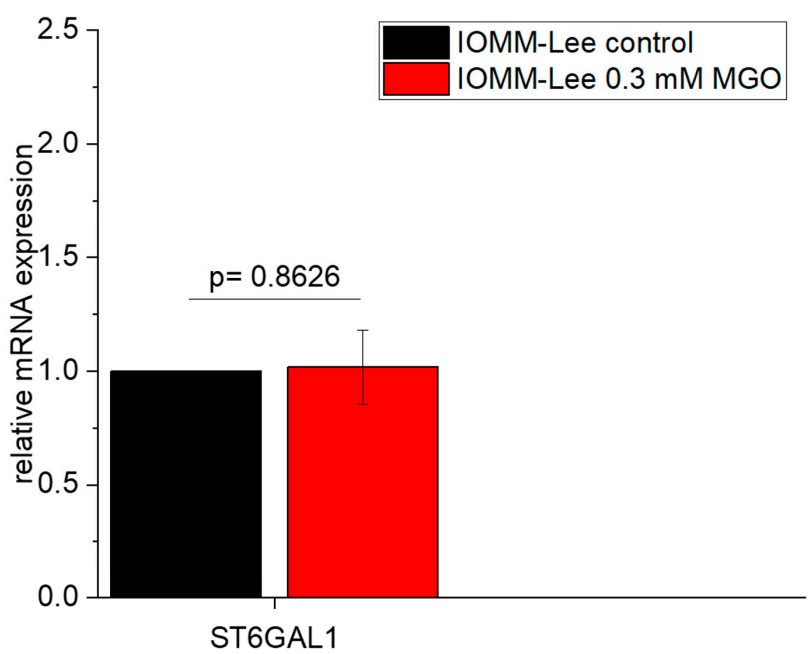

Figure 4. Relative mRNA expression of ST6GAL1-2 in BEN-MEN-1 (A) and IOMM- Lee (B). (A): Normalized control (grey) and mRNA expression after $24 \mathrm{~h}$ treatment with $0.3 \mathrm{mM}$ MGO (green). (B): Normalized control (black) and the mRNA expression after $24 \mathrm{~h}$ treatment with $0.3 \mathrm{mM} \mathrm{MGO}$ (red). Statistical analysis was performed using $t$-test and error bars represent SD ( $n=4$; ST6GAL1: $p=0.0274(\mathbf{A}), p=0.863(\mathbf{B})$; ST6GAL2: $p=0.0213(\mathbf{A})$ ).

Moreover, the mRNA expression of ST6GALNAC1-6 in BEN-MEN-1 (Figure 5A) and IOMM-Lee (Figure 5B) is also differently altered after glycation. ST6GALNAC2 expression decreased after glycation in contrast to the untreated benign cell line $(0.6807 \pm 0.1106$ fold change). ST6GALNAC4 expression is not affected in BEN-MEN-1 (2.556 \pm 1.232 fold change) and IOMM-Lee (1.005 \pm 0.2552 fold change), but glycation decreased the mRNA expression of ST6GALNAC5 in both cell lines $(0.5575 \pm 0.283 ; 0.5991 \pm 0.2174)$. Glycation led to a higher expression of ST6GALNAC6 in the benign cell line (1.5141 \pm 0.1999$)$. ST6GALNAC6 expression is not influenced by glycation in the malignant cell line (0.839 $\pm 0.203)$.

Finally, we quantified the expression of ST8SIA 1-6. Glycation influenced more strongly the expression level of these sialyltransferases in BEN-MEN-1 cells compared to the malignant IOMM-Lee cell line. The expression of ST8SIA1 was highly increased ( $2.696 \pm 0.627$ fold change) after glycation in the benign cell line (Figure 6A) and decreased $(0.744 \pm 0.07712$ fold change) in the glycated malignant cell line (Figure $6 \mathrm{~B})$. The expression of ST8SIA2 (3.2171 \pm 0.6837 fold change) and ST8SIA5 (1.696 \pm 0.3475 fold change) were both increased in BEN-MEN-1 (Figure 6A). ST8SIA5 expression was not influenced by glycation in IOMM-Lee cells. The expression of ST8SIA6 was not influenced by glycation in both cell lines.

\subsection{MGO-Treatment Decreases Ganglioside GM3 Expression in BEN-MEN-1}

To prove that MGO-induced reduction of ST3GAL5 expression has an impact on BENMEN-1 cells, we quantified ganglioside GM3 by PGC nano-LC-ESI-MS/MS. Figure 7A summarizes the biosynthesis of GM3. Figure 7B shows the signal intensity of GM3 before and after glycation in comparison to the internal standard of GT1b in BEN-MEN-1 cells. The absolute quantification of GM3 is shown in Figure 7C. We could show a decreased GM3 expression after glycation $(p=0.00314)$, which is in line with the decreasing expression of ST3GAL5 (see: Figure 3A). The normalized copy numbers of GM3 per cell in the untreated BEN-MEN-1 cell line $\left(1.32 \times 10^{8} \pm 9.15 \times 10^{6}\right)$ were decreased by $235 \%$ compared to the glycated cells $\left(5.61 \times 10^{7} \pm 3.89 \times 10^{6}\right)$. 
A

B
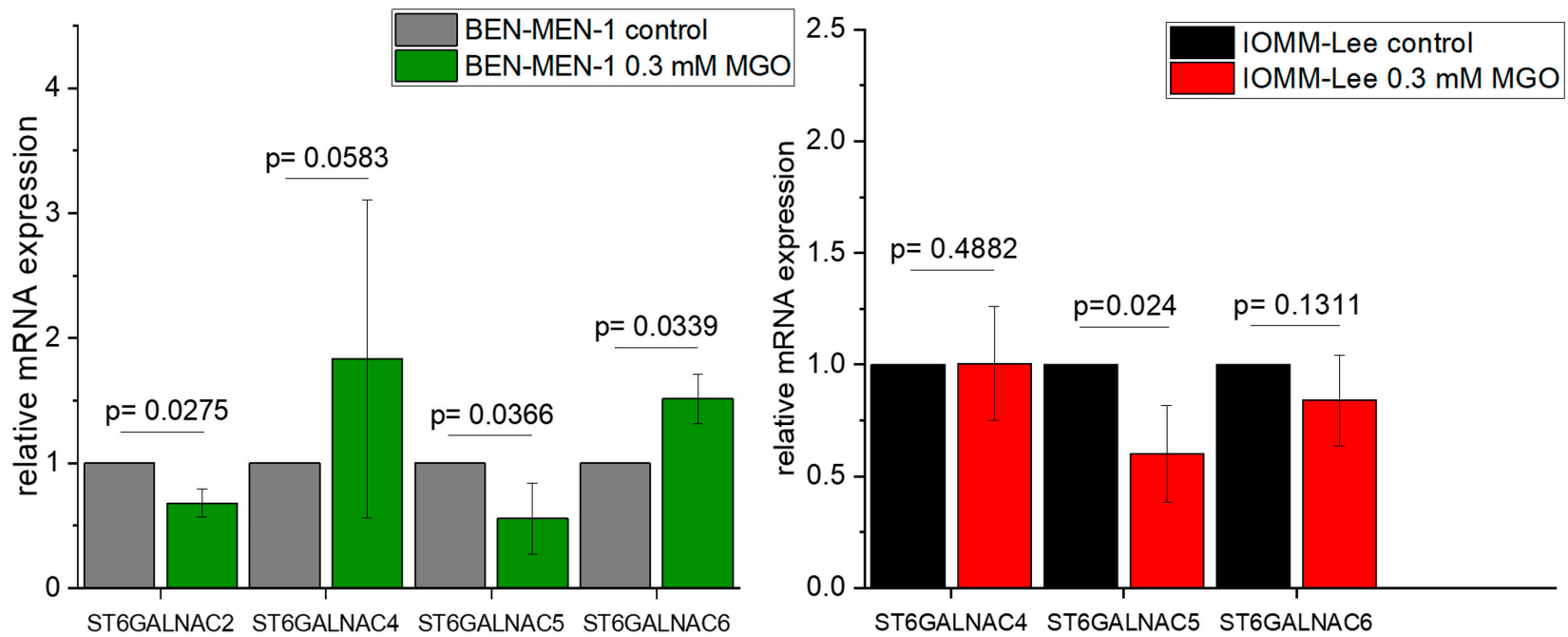

Figure 5. Relative mRNA expression of ST6GALNAC1-6 in BEN-MEN-1 (A) and IOMM- Lee (B). (A): Normalized control (grey) and mRNA expression after $24 \mathrm{~h}$ treatment with $0.3 \mathrm{mM}$ MGO (green). (B): Normalized control (black) and mRNA expression after $24 \mathrm{~h}$ treatment with $0.3 \mathrm{mM}$ MGO (red). Statistical analysis was performed using $t$-test and error bars represent SD ( $\mathrm{n}=4$; ST6GALNAC2: $p=0.0275$ (A); ST6GALNAC4: $p=0.0583(\mathbf{A}), p=0.4882(\mathbf{B})$; ST6GALNAC5: $p=0.0366$ (A), $p=0.024$ (B); ST6GALNAC6: $p=0.0339$ (A), $p=0.1311$ (B)).

A
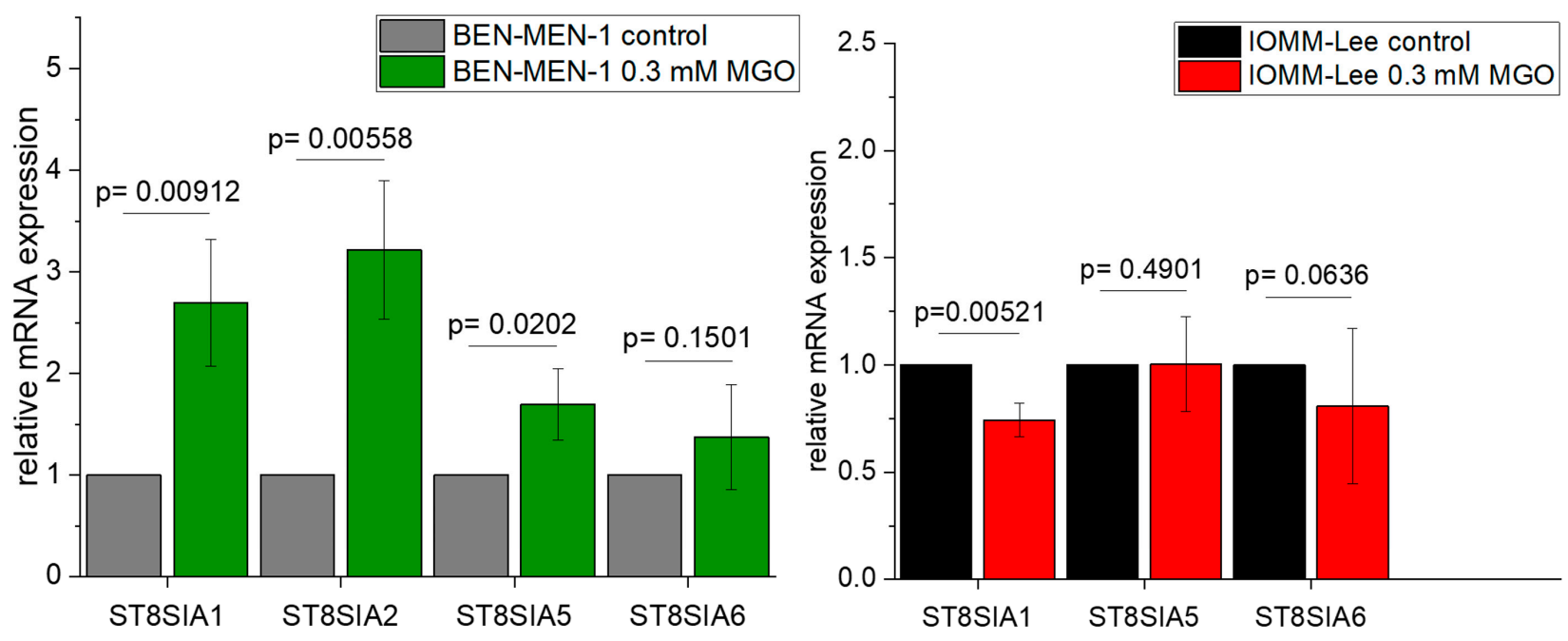

Figure 6. Relative mRNA expression of ST8SIA1-6 in BEN-MEN-1 (A) and IOMM- Lee (B). (A): Normalized control (grey) and mRNA expression after $24 \mathrm{~h}$ treatment with $0.3 \mathrm{mM} \mathrm{MGO}$ (green). (B): Normalized control (black) and mRNA expression after $24 \mathrm{~h}$ treatment with $0.3 \mathrm{mM} \mathrm{MGO}$ (red). Statistical analysis was performed using $t$-test and error bars represent SD ( $\mathrm{n}=4$; ST8SIA1: $p=0.00912(\mathbf{A}), p=0.00521$ (B); ST8SIA2: $p=0.00558$ (A); ST8SIA5: $p=0.0202$ (A), $p=0.4901$ (B); ST8SIA6: $p=0.1501(\mathbf{A}), p=0.0636(\mathbf{B}))$. 

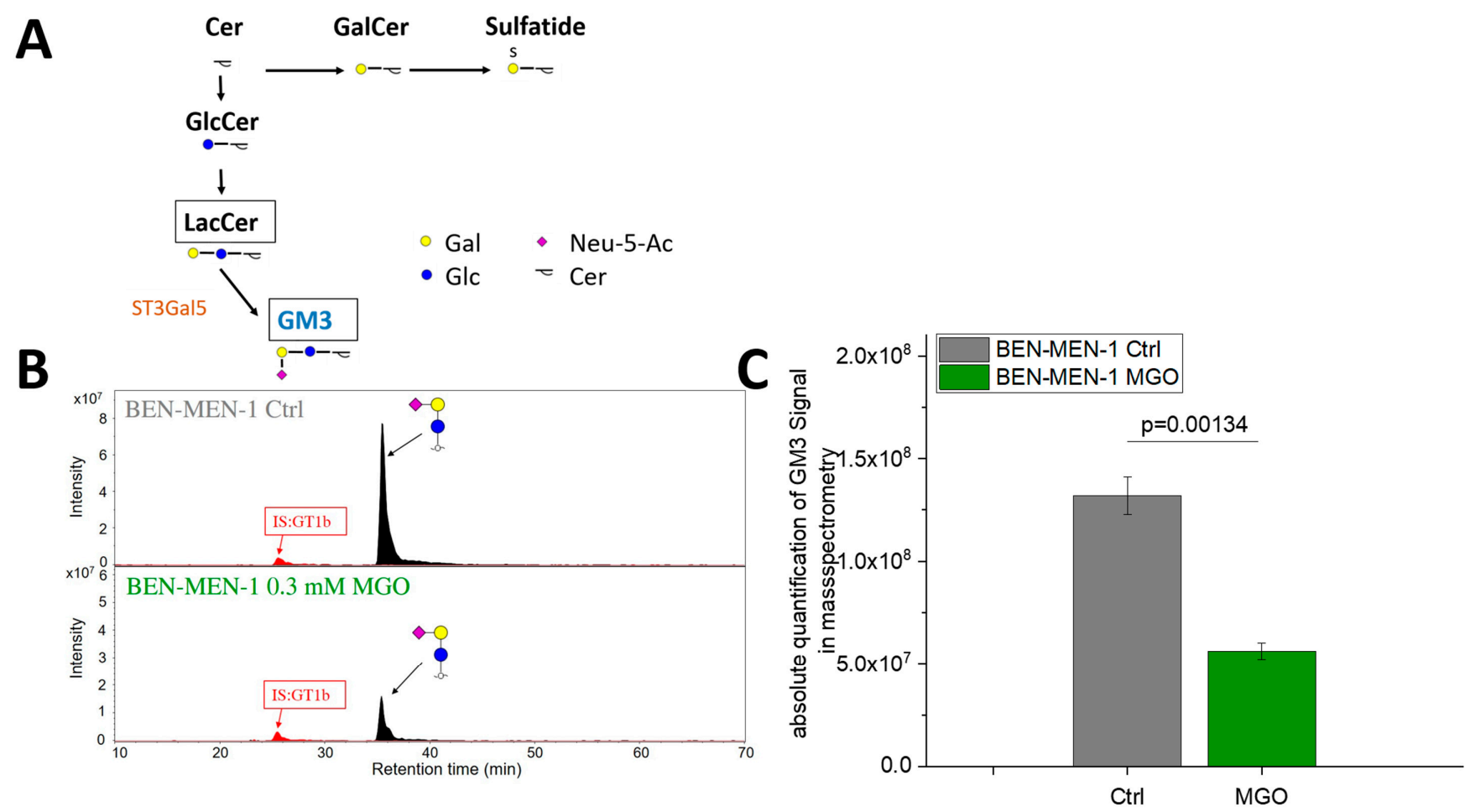

Figure 7. Absolute quantification of GM3 signal by PGC nano-LC-ESI-MS/MS. (A): Schematic representation of the GM3 biosynthesis. Cer = Ceramide; GalCer = Galactosylceramide; GlcCer = Glucosylceramide; LacCer = Lactosylceramide; GM3 = Monosialoganglioside 3. (B): Signal intensity of GM3 in BEN-MEN-1 Ctrl and BEN-MEN-1 0.3 mM MGO in comparison to the internal standard GT1b. (C): Absolute quantification of GM3 signal by PGC nano-LC-ESI-MS/MS of Ctrl (grey) and $0.3 \mathrm{mM}$ MGO-treated BEN-MEN-1 (green). Statistical analysis was performed using $t$-test and error bars represent SD ( $\mathrm{n}=3$; $p=0.00134$ ).

\subsection{Glyoxal-Treatment Has Different Effects in ST3GAL5}

Finally, we analyzed whether another glycation agent than MGO has the same effect on ST3GAL5 expression as MGO. We could show by Western blot analysis that $0.3 \mathrm{mM}$ glyoxal (GO) leads to glycation in both cell lines (data not shown). Using qPCR of cDNA of BEN-MEN-1 cells (Figure 8A) or IOMM-Lee (Figure 8B), which were grown for $24 \mathrm{~h}$ in the presence of $0.3 \mathrm{mM} \mathrm{GO}$, we could show that GO-induced glycation had the same effect on ST3GAL5 expression as MGO treatment in BEN-MEN-1 cells. However, GO did not alter the expression of ST3GAL5 in malignant IOMM-Lee cells, which is in contrast to MGO. This suggests a glycation agent-specific change of ST3GAL5 expression. 
A

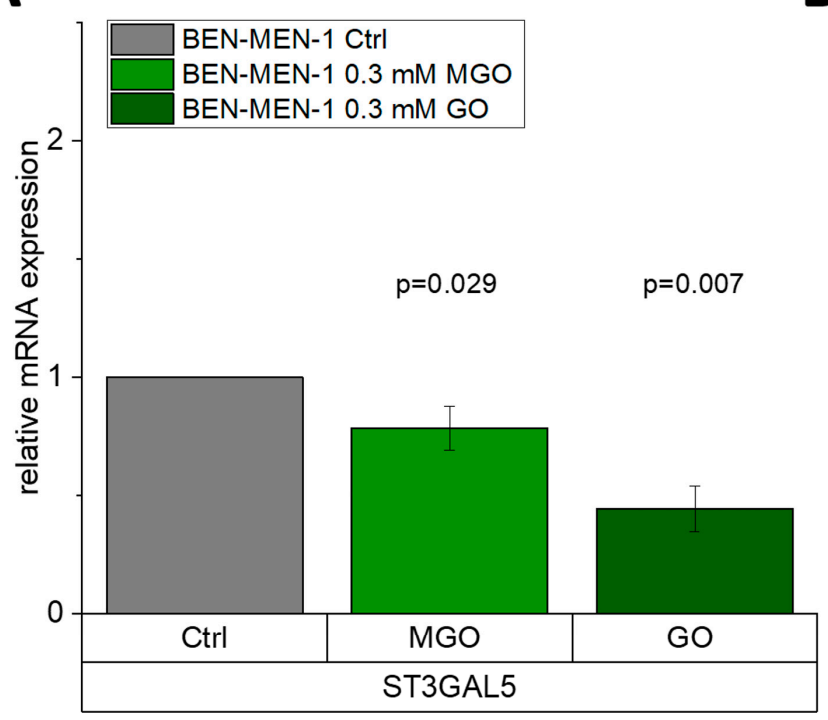

B

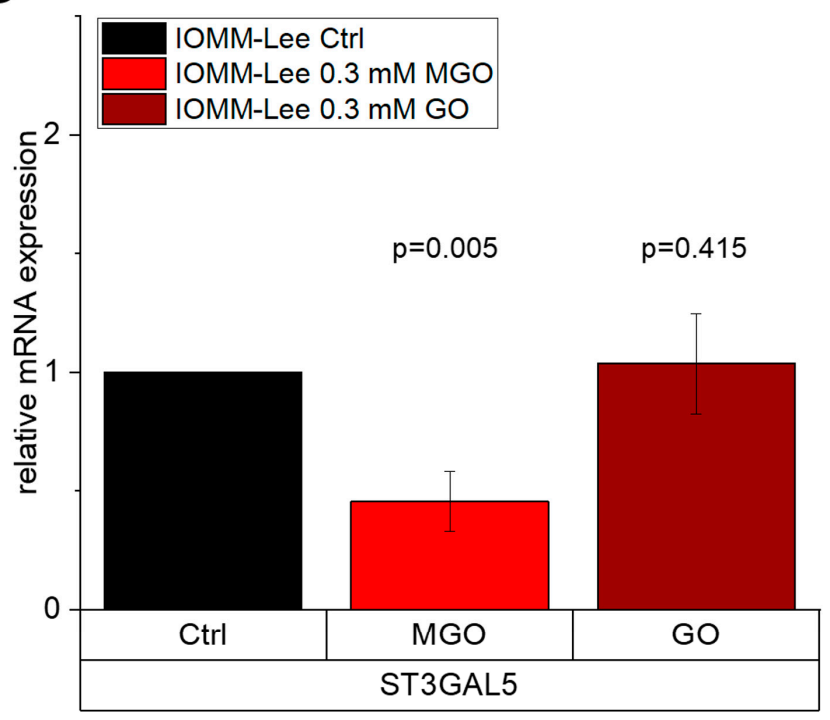

Figure 8. Relative mRNA expression of ST3GAL5 in BEN-MEN-1 (A) and IOMM-Lee (B). A shows the relative expression of ST3GAL5 in untreated (grey), $0.3 \mathrm{mM} \mathrm{MGO}$ (green)- and $0.3 \mathrm{mM} \mathrm{GO}$ (dark green)-treated BEN-MEN-1. B shows the relative expression of ST3GAL5 in untreated (black), $0.3 \mathrm{mM} \mathrm{MGO} \mathrm{(red)-} \mathrm{and} 0.3 \mathrm{mM} \mathrm{GO}$ (dark red)-treated IOMM-Lee. Statistical analysis was performed using $t$-test and error bars represent $\mathrm{SD}(\mathrm{n}=4$; ST3GAL5 GO (A) $p=0.007$; (B) $p=0.415)$.

\section{Discussion}

Many studies demonstrated that sialylation has an impact on tumorigenesis [51-55]. Abnormal levels of different glycosyltransferases were found in different types of human cancers $[56,57]$. In addition, high serum levels of sialyltransferases are associated with the progression of advanced breast cancer [58].

However, little is known about the influence on glycosylation by glycation, which is increased in several cancers because of the Warburg effect $[59,60]$. In this study, we could show, that glycation affects sialylation by modulating ST expression, which could have an impact on different ganglioside patterns and thereby on tumor development. Most of the STs were expressed in both BEN-MEN-1 and IOMM-Lee cell lines. Glycation of both cell lines resulted in an increasing level of STs in the benign meningioma cells and decreasing level in the malignant cells.

There are many reports of changes in ST expression in cancer. Overexpression of ST3GAL1 in ovarian cancer led to transforming growth factor (TGF)- $\beta 1$-induced epithelialmesenchymal-transition, migration, and invasion, and a knockdown resulted in the opposite [61]. Another study by Mehta et al. has revealed that ST3GAL2 and ST6GAL1 were significantly upregulated in tumors with positive perineural invasion status [62], which we observed in the glycated benign cell line. ST3GAL3 was increased in the glycated BEN-MEN-1 cell line but decreased in glycated IOMM-Lee cells. Expression of ST3GAL3 is important for the regulation of biosynthesis of brain disialoganglioside (GD)1a and trisialoganglioside (GT)1b [57]. In several studies, the altered expression of ST3GAL3 has an impact on cell adhesion and invasion. Glycation of meningioma cell lines resulted in decreased ST3GAL5 expression in both cell lines. This sialyltransferase is also known as monosialoganglioside (GM3) synthase [63] and suppresses the epidermal growth factor receptor (EGFR) phosphorylation, which influences the cell proliferation [64] and the cellular resistance to oxidative stress and radiation therapy through upregulation of extracellular signal-regulated kinases (ERK) [42]. The total amount of GM3 was decreased in BEN-MEN-1 cells after glycation. Yamashita and colleagues reported that GM3 synthase knockout mice displayed enhanced ligand-induced insulin receptor phosphorylation. Furthermore, they could show that an increased sensitivity in glucose and insulin tolerance consequently results in an elevated insulin signaling response [65]. Other studies show that 
decreasing expression of GM3 leads to decreased cell motility and cell adhesion through ERK phosphorylation along with Ras upregulation. This regulates migration through mitogen-activated protein kinase (MAPK) $[41,42,66,67]$. The glycating agent GO has the same effect in BEN-MEN-1 cells (downregulation of ST3GAL5) as MGO. However, in IOMM-Lee cells, we observed no effect after glycation with GO, which could be explained by higher glyoxalase 1 activity, which degrades dicarbonyls and has been described in many studies on cancer and glycation [68-70]. The expression of ST3GAL6 was reduced in both glycated meningioma cell lines, which is known to play a key role in the generation of functional Sialyl Lewis X [71]. Decreasing levels of ST3GAL6 can lead to decreasing migration and invasion in 5637 and J82 UBC cells as well as decreasing adhesion and migration in multiple myeloma cells $[72,73]$.

Increased ST6GAL1 expression, as we have shown in glycated BEN-MEN-1 cells, was also found in lung, colon, glioma, prostate, cervical, and breast cancer tissues [74-80]. The downregulation of ST6GAL1 decreased metalloproteinases (MMPs) expression and suppressed invasive potential of A549 and H1299 cells in vitro [79], whereas bladder cancer has ST6GAL1 upregulation, a tumor-suppressive role [81]. The upregulation of ST6GAL2 was found in different types of cancer and was associated with breast cancer with higher expression of intracellular adhesion molecule (ICAM)-1, vascular adhesion molecule (VCAM)-1, CD24, MMP2, MMP9 and C-X-C motif chemokine receptor (CXCR)4 [82,83].

ST6GALNAC2 is known as a metastasis suppressor in breast cancer and a low expression of it, as we observed in glycated BEN-MEN-1 cells, is associated with a bad prognosis $[84,85]$. In Colorectal Carcinoma, Venkitachalam et al. have observed the same [86]. In contrast, Schneider et al. could show, that a high expression of ST6GALNAC2 correlates with metastases to the lymph system [87]. The expression level may be a prognostic marker, but it seems that the mutation of the gene is more important. In our study, ST6GALNAC4 expression was elevated in glycated BEN-MEN-1. High expression of ST6GALNAC4 leads to the prevention of O-glycan chain elongation [88]. In another study of Follicular Thyroid Carcinoma (FTC)-238 cells, the suppression of the ST6GALNAC4 gene led to an inhibition of invasive behavior in vitro and in vivo [89]. The lower expression of ST6GALNAC5 in both glycated meningioma cell lines in our study could be a sign of transformation, because it is restricted to the brain and synthesizes GD1alpha in the nervous tissues [90,91]. We have observed an increased expression of ST6GALNAC6 in glycated BEN-MEN-1 cells. A study in colon cancer has shown that ST6GALNAC6 is responsible for the synthesis of sialyl Lewis (a), which is a significant inductive mechanism in cancer progression [92,93].

The increased expression of ST8SIA1 in glycated BEN-MEN-1 cells could lead to a weak prognosis for patients. In contrast, we observed decreased expression of ST8SIA1 after glycation in IOMM-Lee cells. In melanoma brain metastases, it was shown that ST8SIA1 (GD3 synthases) is upregulated and the GD3 expression is increased, which was associated with a bad prognosis [94]. In gliomas, malignancy increased by higher GD3 and GD2 expression [95]. In addition, ST8SIA1 is one of the key drivers for malignancy in glioblastoma [96]. Mennel et al. reported on different expression levels of GD3 and GD2 in meningiomas, depending on the tumor origin [97]. A study for neuroblastoma and melanoma cells demonstrated that most neuroblastoma cells had a high expression of GD2 and melanoma cells had high expression of GD3 [98]. The increased expression of ST8SIA2, as we observed in glycated BEN-MEN-1 cells, plays a role in the invasive behavior and was significantly associated with the risk of relapse in non-small-cell lung carcinoma [99]. The sialyltransferase ST8Sia5, which is increased in glycated BEN-MEN-1 cells, is known to synthesize GD1c/GT1a/Tetrasialogangliotetraosyl-ceramide (GQ)1b from GM1b/GD1a/GT1b. The group of Schiopu et al. has identified thirty-four distinct glycosphingolipid components (one GM4, nine GM3, two GM2, two GD3, nine GM1, and six GD1) differing in their ceramide compositions [100].

The glycation of meningioma cell lines has opposite effects in benign or malignant meningioma cells. Overall, glycated BEN-MEN-1 cells express more sialyltransferases than unglycated, whereas glycation of IOMM-Lee cells leads to a downregulation of the 
sialyltransferase expression. These observations support our recent observations that glycation of BEN-MEN-1 cells lead to increased invasive potential [30].

\section{Conclusions}

To sum up, glycation of meningioma cell lines has cell line-specific effects. The glycated BEN-MEN-1 cell line is affected in a different expression of ST3GAL1/2/3/5/6; ST6GAL1/2; ST6GALNAC2/6 and ST8SIA1/2. These STs have a direct or indirect impact on tumor progression. The decreased expression of ST3GAL5 after glycation results in a decreasing expression of GM3 in benign meningioma cells. The expression levels of some sialyltransferases (ST3GAL1/2/3; ST6GALNAC5 and ST8SIA1) of the glycated IOMM-Lee cell line were inhibited, which indicates less aggressive behavior.

Author Contributions: Conceptualization, P.S.; methodology, P.S., K.B., M.W. and T.Z.; software, K.B. and P.S.; validation, P.S.; formal analysis, P.S., M.W. and T.Z.; investigation, P.S.; resources, P.S., K.B. and R.H.; data curation, P.S.; writing - original draft preparation, P.S.; writing-review and editing, M.S., R.H. and P.S.; visualization, P.S. and M.S.; supervision, R.H. and C.S.; project administration, R.H., C.S. and M.S.; funding acquisition, R.H., M.S. and C.S. All authors have read and agreed to the published version of the manuscript.

Funding: This research was funded by the Wilhelm Roux Program, FKZ 31/21 and Deutsche Forschungsgemeinschaft (DFG, ProMoAge RTG 2155).

Institutional Review Board Statement: Not applicable.

Informed Consent Statement: Not applicable.

Data Availability Statement: The data presented in this study are available in this article.

Conflicts of Interest: The authors declare no conflict of interest. The funders had no role in the design of the study; in the collection, analyses, or interpretation of data; in the writing of the manuscript, or in the decision to publish the results.

\section{References}

1. Goldbrunner, R.; Minniti, G.; Preusser, M.; Jenkinson, M.D.; Sallabanda, K.; Houdart, E.; von Deimling, A.; Stavrinou, P.; Lefranc, F.; Lund-Johansen, M.; et al. EANO guidelines for the diagnosis and treatment of meningiomas. Lancet Oncol. 2016, 17, e383-e391. [CrossRef]

2. Ostrom, Q.T.; Gittleman, H.; Truitt, G.; Boscia, A.; Kruchko, C.; Barnholtz-Sloan, J.S. CBTRUS Statistical Report: Primary Brain and Other Central Nervous System Tumors Diagnosed in the United States in 2011-2015. Neuro Oncol. 2018, 20, iv1-iv86. [CrossRef]

3. Holleczek, B.; Zampella, D.; Urbschat, S.; Sahm, F.; von Deimling, A.; Oertel, J.; Ketter, R. Incidence, mortality and outcome of meningiomas: A population-based study from Germany. Cancer Epidemiol. 2019, 62, 101562. [CrossRef] [PubMed]

4. $\quad$ Ostrom, Q.T.; Cioffi, G.; Gittleman, H.; Patil, N.; Waite, K.; Kruchko, C.; Barnholtz-Sloan, J.S. CBTRUS Statistical Report: Primary Brain and Other Central Nervous System Tumors Diagnosed in the United States in 2012-2016. Neuro Oncol. 2019, 21, v1-v100. [CrossRef] [PubMed]

5. Maier, A.D.; Bartek, J.; Eriksson, F.; Ugleholdt, H.; Juhler, M.; Broholm, H.; Mathiesen, T.I. Clinical and histopathological predictors of outcome in malignant meningioma. Neurosurg. Rev. 2020, 43, 643-653. [CrossRef] [PubMed]

6. Buerki, R.A.; Horbinski, C.M.; Kruser, T.; Horowitz, P.M.; James, C.D.; Lukas, R.V. An overview of meningiomas. Future Oncol. 2018, 14, 2161-2177. [CrossRef]

7. Champeaux, C.; Jecko, V. World Health Organization grade III meningiomas. A retrospective study for outcome and prognostic factors assessment. Neurochirurgie 2016, 62, 203-208. [CrossRef]

8. Peyre, M.; Gauchotte, G.; Giry, M.; Froehlich, S.; Pallud, J.; Graillon, T.; Bielle, F.; Cazals-Hatem, D.; Varlet, P.; Figarella-Branger, D.; et al. De novo and secondary anaplastic meningiomas: A study of clinical and histomolecular prognostic factors. Neuro Oncol. 2018, 20, 1113-1121. [CrossRef]

9. Claus, E.B.; Bondy, M.L.; Schildkraut, J.M.; Wiemels, J.L.; Wrensch, M.; Black, P.M. Epidemiology of intracranial meningioma. Neurosurgery 2005, 57, 1088-1095. [CrossRef]

10. Pasquier, D.; Bijmolt, S.; Veninga, T.; Rezvoy, N.; Villa, S.; Krengli, M.; Weber, D.C.; Baumert, B.G.; Canyilmaz, E.; Yalman, D.; et al. Atypical and malignant meningioma: Outcome and prognostic factors in 119 irradiated patients. A multicenter, retrospective study of the Rare Cancer Network. Int. J. Radiat. Oncol. Biol. Phys. 2008, 71, 1388-1393. [CrossRef]

11. Allaman, I.; Bélanger, M.; Magistretti, P.J. Methylglyoxal, the dark side of glycolysis. Front. Neurosci. 2015, 9, 23. [CrossRef] [PubMed] 
12. Bharadwaj, S.; Venkatraghavan, L.; Mariappan, R.; Ebinu, J.; Meng, Y.; Khan, O.; Tung, T.; Reyhani, S.; Bernstein, M.; Zadeh, G. Serum lactate as a potential biomarker of non-glial brain tumors. J. Clin. Neurosci. 2015, 22, 1625-1627. [CrossRef] [PubMed]

13. Gill, K.S.; Fernandes, P.; O’Donovan, T.R.; McKenna, S.L.; Doddakula, K.K.; Power, D.G.; Soden, D.M.; Forde, P.F. Glycolysis inhibition as a cancer treatment and its role in an anti-tumour immune response. Biochim. Biophys. Acta 2016, 1866, 87-105. [CrossRef]

14. Rabbani, N.; Thornalley, P.J. Dicarbonyl stress in cell and tissue dysfunction contributing to ageing and disease. Biochem. Biophys. Res. Commun. 2015, 458, 221-226. [CrossRef]

15. Giovannucci, E.; Harlan, D.M.; Archer, M.C.; Bergenstal, R.M.; Gapstur, S.M.; Habel, L.A.; Pollak, M.; Regensteiner, J.G.; Yee, D. Diabetes and cancer: A consensus report. CA Cancer J. Clin. 2010, 60, 207-221. [CrossRef] [PubMed]

16. Chowdhury, T.A. Diabetes and cancer. QJM 2010, 103, 905-915. [CrossRef]

17. Michaud, D.S.; Bové, G.; Gallo, V.; Schlehofer, B.; Tjønneland, A.; Olsen, A.; Overvad, K.; Dahm, C.C.; Teucher, B.; Boeing, H.; et al. Anthropometric measures, physical activity, and risk of glioma and meningioma in a large prospective cohort study. Cancer Prev. Res. 2011, 4, 1385-1392. [CrossRef]

18. Edlinger, M.; Strohmaier, S.; Jonsson, H.; Bjørge, T.; Manjer, J.; Borena, W.T.; Häggström, C.; Engeland, A.; Tretli, S.; Concin, H.; et al. Blood pressure and other metabolic syndrome factors and risk of brain tumour in the large population-based Me-Can cohort study. J. Hypertens. 2012, 30, 290-296. [CrossRef]

19. Schneider, B.; Pülhorn, H.; Röhrig, B.; Rainov, N.G. Predisposing conditions and risk factors for development of symptomatic meningioma in adults. Cancer Detect. Prev. 2005, 29, 440-447. [CrossRef]

20. Schwartzbaum, J.; Jonsson, F.; Ahlbom, A.; Preston-Martin, S.; Malmer, B.; Lönn, S.; Söderberg, K.; Feychting, M. Prior hospitalization for epilepsy, diabetes, and stroke and subsequent glioma and meningioma risk. Cancer Epidemiol. Biomark. Prev. 2005, 14, 643-650. [CrossRef]

21. Bernardo, B.M.; Orellana, R.C.; Weisband, Y.L.; Hammar, N.; Walldius, G.; Malmstrom, H.; Ahlbom, A.; Feychting, M.; Schwartzbaum, J. Association between prediagnostic glucose, triglycerides, cholesterol and meningioma, and reverse causality. Br. J. Cancer 2016, 115, 108-114. [CrossRef]

22. Nayeri, A.; Chotai, S.; Prablek, M.A.; Brinson, P.R.; Douleh, D.G.; Weaver, K.D.; Thompson, R.C.; Chambless, L. Type 2 diabetes is an independent negative prognostic factor in patients undergoing surgical resection of a WHO grade I meningioma. Clin. Neurol. Neurosurg. 2016, 149, 6-10. [CrossRef] [PubMed]

23. Ahmed, N. Advanced glycation endproducts-role in pathology of diabetic complications. Diabetes Res. Clin. Pract. 2005, 67, 3-21. [CrossRef] [PubMed]

24. Rabbani, N.; Thornalley, P.J. The dicarbonyl proteome: Proteins susceptible to dicarbonyl glycation at functional sites in health, aging, and disease. Ann. N. Y. Acad. Sci. 2008, 1126, 124-127. [CrossRef]

25. Thornalley, P.J.; Langborg, A.; Minhas, H.S. Formation of glyoxal, methylglyoxal and 3-deoxyglucosone in the glycation of proteins by glucose. Biochem. J. 1999, 344 Pt 1, 109-116. [CrossRef]

26. Brings, S.; Fleming, T.; Freichel, M.; Muckenthaler, M.U.; Herzig, S.; Nawroth, P.P. Dicarbonyls and Advanced Glycation EndProducts in the Development of Diabetic Complications and Targets for Intervention. Int. J. Mol. Sci. 2017, 18, 984. [CrossRef] [PubMed]

27. Kalapos, M.P. Methylglyoxal and glucose metabolism: A historical perspective and future avenues for research. Drug Metabol. Drug Interact. 2008, 23, 69-91. [CrossRef] [PubMed]

28. Falone, S.; D'Alessandro, A.; Mirabilio, A.; Petruccelli, G.; Cacchio, M.; Di Ilio, C.; Di Loreto, S.; Amicarelli, F. Long term running biphasically improves methylglyoxal-related metabolism, redox homeostasis and neurotrophic support within adult mouse brain cortex. PLoS ONE 2012, 7, e31401. [CrossRef]

29. Schalkwijk, C.G. Vascular AGE-ing by methylglyoxal: The past, the present and the future. Diabetologia 2015, 58, 1715-1719. [CrossRef]

30. Selke, P.; Rosenstock, P.; Bork, K.; Strauss, C.; Horstkorte, R.; Scheer, M. Glycation of benign meningioma cells leads to increased invasion. Biol. Chem. 2021. [CrossRef]

31. Bellahcène, A.; Nokin, M.-J.; Castronovo, V.; Schalkwijk, C. Methylglyoxal-derived stress: An emerging biological factor involved in the onset and progression of cancer. Semin. Cancer Biol. 2018, 49, 64-74. [CrossRef] [PubMed]

32. Antognelli, C.; Moretti, S.; Frosini, R.; Puxeddu, E.; Sidoni, A.; Talesa, V.N. Methylglyoxal Acts as a Tumor-Promoting Factor in Anaplastic Thyroid Cancer. Cells 2019, 8, 547. [CrossRef] [PubMed]

33. Takashima, S.; Tsuji, S.; Tsujimoto, M. Characterization of the second type of human beta-galactoside alpha 2,6-sialyltransferase (ST6Gal II), which sialylates Galbeta 1,4GlcNAc structures on oligosaccharides preferentially. Genomic analysis of human sialyltransferase genes. J. Biol. Chem. 2002, 277, 45719-45728. [CrossRef] [PubMed]

34. Comb, D.G.; Roseman, S. The sialic acids. I. The structure and enzymatic synthesis of N-acetylneuraminic acid. J. Biol. Chem. 1960, 235, 2529-2537. [CrossRef]

35. Stäsche, R.; Hinderlich, S.; Weise, C.; Effertz, K.; Lucka, L.; Moormann, P.; Reutter, W. A bifunctional enzyme catalyzes the first two steps in $\mathrm{N}$-acetylneuraminic acid biosynthesis of rat liver. Molecular cloning and functional expression of UDP-N-acetylglucosamine 2-epimerase/N-acetylmannosamine kinase. J. Biol. Chem. 1997, 272, 24319-24324. [CrossRef]

36. Harduin-Lepers, A.; Vallejo-Ruiz, V.; Krzewinski-Recchi, M.-A.; Samyn-Petit, B.; Julien, S.; Delannoy, P. The human sialyltransferase family. Biochimie 2001, 83, 727-737. [CrossRef] 
37. Datta, A.K. Comparative sequence analysis in the sialyltransferase protein family: Analysis of motifs. Curr. Drug Targets 2009, 10, 483-498. [CrossRef]

38. Lau, K.S.; Partridge, E.A.; Grigorian, A.; Silvescu, C.I.; Reinhold, V.N.; Demetriou, M.; Dennis, J.W. Complex N-glycan number and degree of branching cooperate to regulate cell proliferation and differentiation. Cell 2007, 129, 123-134. [CrossRef]

39. Taganna, J.; de Boer, A.R.; Wuhrer, M.; Bouckaert, J. Glycosylation changes as important factors for the susceptibility to urinary tract infection. Biochem. Soc. Trans. 2011, 39, 349-354. [CrossRef]

40. Uemura, S.; Go, S.; Shishido, F.; Inokuchi, J.-i. Expression machinery of GM4: The excess amounts of GM3/GM4S synthase (ST3GAL5) are necessary for GM4 synthesis in mammalian cells. Glycoconj. J. 2014, 31, 101-108. [CrossRef]

41. Hakomori, S.-I.; Handa, K. GM3 and cancer. Glycoconj. J. 2015, 32, 1-8. [CrossRef] [PubMed]

42. Shimizu, T.; Nagane, M.; Suzuki, M.; Yamauchi, A.; Kato, K.; Kawashima, N.; Nemoto, Y.; Maruo, T.; Kawakami, Y.; Yamashita, T. Tumor hypoxia regulates ganglioside GM3 synthase, which contributes to oxidative stress resistance in malignant melanoma. Biochim. Biophys. Acta Gen. Subj. 2020, 1864, 129723. [CrossRef]

43. Inokuchi, J.-i.; Inamori, K.-I.; Kabayama, K.; Nagafuku, M.; Uemura, S.; Go, S.; Suzuki, A.; Ohno, I.; Kanoh, H.; Shishido, F. Biology of GM3 Ganglioside. Prog. Mol. Biol. Transl. Sci. 2018, 156, 151-195. [CrossRef] [PubMed]

44. Rosenstock, P.; Bork, K.; Massa, C.; Selke, P.; Seliger, B.; Horstkorte, R. Sialylation of Human Natural Killer (NK) Cells is Regulated by IL-2. J. Clin. Med. 2020, 9, 1816. [CrossRef] [PubMed]

45. Zhang, T.; van Die, I.; Tefsen, B.; van Vliet, S.J.; Laan, L.C.; Zhang, J.; ten Dijke, P.; Wuhrer, M.; Belo, A.I. Differential Oand Glycosphingolipid Glycosylation in Human Pancreatic Adenocarcinoma Cells With Opposite Morphology and Metastatic Behavior. Front. Oncol. 2020, 10, 732. [CrossRef]

46. Jensen, P.H.; Karlsson, N.G.; Kolarich, D.; Packer, N.H. Structural analysis of N- and O-glycans released from glycoproteins. Nat. Protoc. 2012, 7, 1299-1310. [CrossRef]

47. Anugraham, M.; Everest-Dass, A.V.; Jacob, F.; Packer, N.H. A platform for the structural characterization of glycans enzymatically released from glycosphingolipids extracted from tissue and cells. Rapid Commun. Mass Spectrom. 2015, 29, 545-561. [CrossRef]

48. Karlsson, N.G.; Wilson, N.L.; Wirth, H.-J.; Dawes, P.; Joshi, H.; Packer, N.H. Negative ion graphitised carbon nano-liquid chromatography/mass spectrometry increases sensitivity for glycoprotein oligosaccharide analysis. Rapid Commun. Mass Spectrom. 2004, 18, 2282-2292. [CrossRef]

49. Ceroni, A.; Maass, K.; Geyer, H.; Geyer, R.; Dell, A.; Haslam, S.M. GlycoWorkbench: A tool for the computer-assisted annotation of mass spectra of glycans. J. Proteome Res. 2008, 7, 1650-1659. [CrossRef]

50. Cooper, C.A.; Gasteiger, E.; Packer, N.H. GlycoMod-A software tool for determining glycosylation compositions from mass spectrometric data. Proteomics 2001, 1, 340-349. [CrossRef]

51. Pihikova, D.; Kasak, P.; Kubanikova, P.; Sokol, R.; Tkac, J. Aberrant sialylation of a prostate-specific antigen: Electrochemical label-free glycoprofiling in prostate cancer serum samples. Anal. Chim. Acta 2016, 934, 72-79. [CrossRef]

52. Yoneyama, T.; Ohyama, C.; Hatakeyama, S.; Narita, S.; Habuchi, T.; Koie, T.; Mori, K.; Hidari, K.I.P.J.; Yamaguchi, M.; Suzuki, T.; et al. Measurement of aberrant glycosylation of prostate specific antigen can improve specificity in early detection of prostate cancer. Biochem. Biophys. Res. Commun. 2014, 448, 390-396. [CrossRef]

53. Vučković, F.; Theodoratou, E.; Thaçi, K.; Timofeeva, M.; Vojta, A.; Štambuk, J.; Pučić-Baković, M.; Rudd, P.M.; Đerek, L.; Servis, D.; et al. IgG Glycome in Colorectal Cancer. Clin. Cancer Res. 2016, 22, 3078-3086. [CrossRef] [PubMed]

54. Fleming, S.C.; Smith, S.; Knowles, D.; Skillen, A.; Self, C.H. Increased sialylation of oligosaccharides on IgG paraproteins-A potential new tumour marker in multiple myeloma. J. Clin. Pathol. 1998, 51, 825-830. [CrossRef] [PubMed]

55. Saldova, R.; Wormald, M.R.; Dwek, R.A.; Rudd, P.M. Glycosylation changes on serum glycoproteins in ovarian cancer may contribute to disease pathogenesis. Dis. Markers 2008, 25, 219-232. [CrossRef]

56. Suzuki, O.; Abe, M.; Hashimoto, Y. Sialylation by $\beta$-galactoside $\alpha-2,6$-sialyltransferase and N-glycans regulate cell adhesion and invasion in human anaplastic large cell lymphoma. Int. J. Oncol. 2015, 46, 973-980. [CrossRef] [PubMed]

57. Cui, H.-X.; Wang, H.; Wang, Y.; Song, J.; Tian, H.; Xia, C.; Shen, Y. ST3Gal III modulates breast cancer cell adhesion and invasion by altering the expression of invasion-related molecules. Oncol. Rep. 2016, 36, 3317-3324. [CrossRef]

58. Dao, T.L.; Ip, C.; Patel, J. Serum sialyltransferase and 5'-nucleotidase as reliable biomarkers in women with breast cancer. J. Natl. Cancer Inst. 1980, 65, 529-534.

59. Ahmad, S.; Khan, H.; Siddiqui, Z.; Khan, M.Y.; Rehman, S.; Shahab, U.; Godovikova, T.; Silnikov, V. AGEs, RAGEs and s-RAGE; friend or foe for cancer. Semin. Cancer Biol. 2018, 49, 44-55. [CrossRef]

60. Bellier, J.; Nokin, M.-J.; Lardé, E.; Karoyan, P.; Peulen, O.; Castronovo, V.; Bellahcène, A. Methylglyoxal, a potent inducer of AGEs, connects between diabetes and cancer. Diabetes Res. Clin. Pract. 2019, 148, 200-211. [CrossRef]

61. Wu, X.; Zhao, J.; Ruan, Y.; Sun, L.; Xu, C.; Jiang, H. Sialyltransferase ST3GAL1 promotes cell migration, invasion, and TGF- $\beta 1-$ induced EMT and confers paclitaxel resistance in ovarian cancer. Cell Death Dis. 2018, 9, 1102. [CrossRef] [PubMed]

62. Mehta, K.A.; Patel, K.A.; Pandya, S.J.; Patel, P.S. Aberrant sialylation plays a significant role in oral squamous cell carcinoma progression. J. Oral Pathol. Med. 2020, 49, 253-259. [CrossRef] [PubMed]

63. Trinchera, M.; Parini, R.; Indellicato, R.; Domenighini, R.; dall'Olio, F. Diseases of ganglioside biosynthesis: An expanding group of congenital disorders of glycosylation. Mol. Genet. Metab. 2018, 124, 230-237. [CrossRef]

64. Kawashima, N.; Nishimiya, Y.; Takahata, S.; Nakayama, K.-I. Induction of Glycosphingolipid GM3 Expression by Valproic Acid Suppresses Cancer Cell Growth. J. Biol. Chem. 2016, 291, 21424-21433. [CrossRef] 
65. Yamashita, T.; Hashiramoto, A.; Haluzik, M.; Mizukami, H.; Beck, S.; Norton, A.; Kono, M.; Tsuji, S.; Daniotti, J.L.; Werth, N.; et al. Enhanced insulin sensitivity in mice lacking ganglioside GM3. Proc. Natl. Acad. Sci. USA 2003, 100, 3445-3449. [CrossRef]

66. Kojima, N.; Hakomori, S. Cell adhesion, spreading, and motility of GM3-expressing cells based on glycolipid-glycolipid interaction. J. Biol. Chem. 1991, 266, 17552-17558. [CrossRef]

67. Hashiramoto, A.; Mizukami, H.; Yamashita, T. Ganglioside GM3 promotes cell migration by regulating MAPK and c-Fos/AP-1. Oncogene 2006, 25, 3948-3955. [CrossRef] [PubMed]

68. Hu, X.; Yang, X.; He, Q.; Chen, Q.; Yu, L. Glyoxalase 1 is up-regulated in hepatocellular carcinoma and is essential for HCC cell proliferation. Biotechnol. Lett. 2014, 36, 257-263. [CrossRef] [PubMed]

69. Peng, H.-T.; Chen, J.; Liu, T.-Y.; Wu, Y.-Q.; Lin, X.-H.; Lai, Y.-H.; Huang, Y.-F. Up-regulation of the tumor promoter Glyoxalase-1 indicates poor prognosis in breast cancer. Int. J. Clin. Exp. Pathol. 2017, 10, 10852-10862.

70. Burdelski, C.; Shihada, R.; Hinsch, A.; Angerer, A.; Göbel, C.; Friedrich, E.; Hube-Magg, C.; Burdak-Rothkamm, S.; Kluth, M.; Simon, R.; et al. High-Level Glyoxalase 1 (GLO1) expression is linked to poor prognosis in prostate cancer. Prostate 2017, 77, 1528-1538. [CrossRef]

71. Chachadi, V.B.; Bhat, G.; Cheng, P.-W. Glycosyltransferases involved in the synthesis of MUC-associated metastasis-promoting selectin ligands. Glycobiology 2015, 25, 963-975. [CrossRef]

72. Dalangood, S.; Zhu, Z.; Ma, Z.; Li, J.; Zeng, Q.; Yan, Y.; Shen, B.; Yan, J.; Huang, R. Identification of glycogene-type and validation of ST3GAL6 as a biomarker predicts clinical outcome and cancer cell invasion in urinary bladder cancer. Theranostics 2020, 10, 10078-10091. [CrossRef]

73. Glavey, S.V.; Manier, S.; Natoni, A.; Sacco, A.; Moschetta, M.; Reagan, M.R.; Murillo, L.S.; Sahin, I.; Wu, P.; Mishima, Y.; et al. The sialyltransferase ST3GAL6 influences homing and survival in multiple myeloma. Blood 2014, 124, 1765-1776. [CrossRef] [PubMed]

74. Lin, S.; Kemmner, W.; Grigull, S.; Schlag, P.M. Cell surface alpha 2,6 sialylation affects adhesion of breast carcinoma cells. Exp. Cell Res. 2002, 276, 101-110. [CrossRef] [PubMed]

75. Lu, J.; Isaji, T.; Im, S.; Fukuda, T.; Hashii, N.; Takakura, D.; Kawasaki, N.; Gu, J. $\beta$-Galactoside $\alpha 2,6$-sialyltranferase 1 promotes transforming growth factor- $\beta$-mediated epithelial-mesenchymal transition. J. Biol. Chem. 2014, 289, 34627-34641. [CrossRef]

76. Swindall, A.F.; Bellis, S.L. Sialylation of the Fas death receptor by ST6Gal-I provides protection against Fas-mediated apoptosis in colon carcinoma cells. J. Biol. Chem. 2011, 286, 22982-22990. [CrossRef]

77. Wang, P.-H.; Lee, W.-L.; Lee, Y.-R.; Juang, C.-M.; Chen, Y.-J.; Chao, H.-T.; Tsai, Y.-C.; Yuan, C.-C. Enhanced expression of $\alpha$ 2,6-sialyltransferase ST6Gal I in cervical squamous cell carcinoma. Gynecol. Oncol. 2003, 89, 395-401. [CrossRef]

78. Wei, A.; Fan, B.; Zhao, Y.; Zhang, H.; Wang, L.; Yu, X.; Yuan, Q.; Yang, D.; Wang, S. ST6Gal-I overexpression facilitates prostate cancer progression via the PI3K/Akt/GSK-3 $\beta / \beta$-catenin signaling pathway. Oncotarget 2016, 7, 65374-65388. [CrossRef] [PubMed]

79. Yuan, Q.; Chen, X.; Han, Y.; Lei, T.; Wu, Q.; Yu, X.; Wang, L.; Fan, Z.; Wang, S. Modification of $\alpha 2$,6-sialylation mediates the invasiveness and tumorigenicity of non-small cell lung cancer cells in vitro and in vivo via Notch1/Hes1/MMPs pathway. Int. J. Cancer 2018, 143, 2319-2330. [CrossRef]

80. Yamamoto, H.; Oviedo, A.; Sweeley, C.; Saito, T.; Moskal, J.R. Alpha2,6-sialylation of cell-surface N-glycans inhibits glioma formation in vivo. Cancer Res. 2001, 61, 6822-6829.

81. Antony, P.; Rose, M.; Heidenreich, A.; Knüchel, R.; Gaisa, N.T.; Dahl, E. Epigenetic inactivation of ST6GAL1 in human bladder cancer. BMC Cancer 2014, 14, 901. [CrossRef] [PubMed]

82. Cheng, J.; Wang, R.; Zhong, G.; Chen, X.; Cheng, Y.; Li, W.; Yang, Y. ST6GAL2 Downregulation Inhibits Cell Adhesion and Invasion and is Associated with Improved Patient Survival in Breast Cancer. Onco. Targets. Ther. 2020, 13, 903-914. [CrossRef] [PubMed]

83. Xu, G.; Chen, J.; Wang, G.; Xiao, J.; Zhang, N.; Chen, Y.; Yu, H.; Wang, G.; Zhao, Y. Resveratrol Inhibits the Tumorigenesis of Follicular Thyroid Cancer via ST6GAL2-Regulated Activation of the Hippo Signaling Pathway. Mol. Ther. Oncolytics 2020, 16, 124-133. [CrossRef] [PubMed]

84. Ferrer, C.M.; Reginato, M.J. Sticking to sugars at the metastatic site: Sialyltransferase ST6GalNAc2 acts as a breast cancer metastasis suppressor. Cancer Discov. 2014, 4, 275-277. [CrossRef]

85. Murugaesu, N.; Iravani, M.; van Weverwijk, A.; Ivetic, A.; Johnson, D.A.; Antonopoulos, A.; Fearns, A.; Jamal-Hanjani, M.; Sims, D.; Fenwick, K.; et al. An in vivo functional screen identifies ST6GalNAc2 sialyltransferase as a breast cancer metastasis suppressor. Cancer Discov. 2014, 4, 304-317. [CrossRef]

86. Venkitachalam, S.; Revoredo, L.; Varadan, V.; Fecteau, R.E.; Ravi, L.; Lutterbaugh, J.; Markowitz, S.D.; Willis, J.E.; Gerken, T.A.; Guda, K. Biochemical and functional characterization of glycosylation-associated mutational landscapes in colon cancer. Sci. Rep. 2016, 6, 23642. [CrossRef]

87. Schneider, F.; Kemmner, W.; Haensch, W.; Franke, G.; Gretschel, S.; Karsten, U.; Schlag, P.M. Overexpression of sialyltransferase CMP-sialic acid:Galbeta1,3GalNAc-R alpha6-Sialyltransferase is related to poor patient survival in human colorectal carcinomas. Cancer Res. 2001, 61, 4605-4611.

88. Reticker-Flynn, N.E.; Bhatia, S.N. Aberrant glycosylation promotes lung cancer metastasis through adhesion to galectins in the metastatic niche. Cancer Discov. 2015, 5, 168-181. [CrossRef] 
89. Miao, X.; Jia, L.; Zhou, H.; Song, X.; Zhou, M.; Xu, J.; Zhao, L.; Feng, X.; Zhao, Y. miR-4299 mediates the invasive properties and tumorigenicity of human follicular thyroid carcinoma by targeting ST6GALNAC4. IUBMB Life 2016, 68, 136-144. [CrossRef]

90. Bos, P.D.; Zhang, X.H.-F.; Nadal, C.; Shu, W.; Gomis, R.R.; Nguyen, D.X.; Minn, A.J.; van de Vijver, M.J.; Gerald, W.L.; Foekens, J.A.; et al. Genes that mediate breast cancer metastasis to the brain. Nature 2009, 459, 1005-1009. [CrossRef]

91. Okajima, T.; Fukumoto, S.; Ito, H.; Kiso, M.; Hirabayashi, Y.; Urano, T.; Furukawa, K. Molecular cloning of brain-specific GD1alpha synthase (ST6GalNAc V) containing CAG/Glutamine repeats. J. Biol. Chem. 1999, 274, 30557-30562. [CrossRef] [PubMed]

92. Kannagi, R. Carbohydrate antigen sialyl Lewis a-its pathophysiological significance and induction mechanism in cancer progression. Chang Gung Med. J. 2007, 30, 189-209.

93. Tsuchida, A.; Okajima, T.; Furukawa, K.; Ando, T.; Ishida, H.; Yoshida, A.; Nakamura, Y.; Kannagi, R.; Kiso, M.; Furukawa, K. Synthesis of disialyl Lewis a (Le(a)) structure in colon cancer cell lines by a sialyltransferase, ST6GalNAc VI, responsible for the synthesis of alpha-series gangliosides. J. Biol. Chem. 2003, 278, 22787-22794. [CrossRef]

94. Ramos, R.I.; Bustos, M.A.; Wu, J.; Jones, P.; Chang, S.C.; Kiyohara, E.; Tran, K.; Zhang, X.; Stern, S.L.; Izraely, S.; et al. Upregulation of cell surface GD3 ganglioside phenotype is associated with human melanoma brain metastasis. Mol. Oncol. 2020, 14, 1760-1778. [CrossRef]

95. Iwasawa, T.; Zhang, P.; Ohkawa, Y.; Momota, H.; Wakabayashi, T.; Ohmi, Y.; Bhuiyan, R.H.; Furukawa, K.; Furukawa, K. Enhancement of malignant properties of human glioma cells by ganglioside GD3/GD2. Int. J. Oncol. 2018, 52, $1255-1266$. [CrossRef] [PubMed]

96. Yeh, S.-C.; Wang, P.-Y.; Lou, Y.-W.; Khoo, K.-H.; Hsiao, M.; Hsu, T.-L.; Wong, C.-H. Glycolipid GD3 and GD3 synthase are key drivers for glioblastoma stem cells and tumorigenicity. Proc. Natl. Acad. Sci. USA 2016, 113, 5592-5597. [CrossRef] [PubMed]

97. Mennel, H.D.; Bosslet, K.; Geissel, H.; Bauer, B.L. Immunohistochemically visualized localisation of gangliosides Glac2 (GD3) and Gtri2 (GD2) in cells of human intracranial tumors. Exp. Toxicol. Pathol. 2000, 52, 277-285. [CrossRef]

98. Ruan, S.; Raj, B.K.; Lloyd, K.O. Relationship of glycosyltransferases and mRNA levels to ganglioside expression in neuroblastoma and melanoma cells. J. Neurochem. 1999, 72, 514-521. [CrossRef] [PubMed]

99. Hao, J.; Zeltz, C.; Pintilie, M.; Li, Q.; Sakashita, S.; Wang, T.; Cabanero, M.; Martins-Filho, S.N.; Wang, D.Y.; Pasko, E.; et al. Characterization of Distinct Populations of Carcinoma-Associated Fibroblasts from Non-Small Cell Lung Carcinoma Reveals a Role for ST8SIA2 in Cancer Cell Invasion. Neoplasia 2019, 21, 482-493. [CrossRef]

100. Schiopu, C.; Vukelić, Z.; Capitan, F.; Kalanj-Bognar, S.; Sisu, E.; Zamfir, A.D. Chip-nanoelectrospray quadrupole time-of-flight tandem mass spectrometry of meningioma gangliosides: A preliminary study. Electrophoresis 2012, 33, 1778-1786. [CrossRef] 